\title{
Resilience thinking and urban planning in a coastal environment at risks of tsunamis: the case study of Mehuín, Chile ${ }^{1}$
}

\author{
Paula Villagra², Geraldine Herrmann ${ }^{3}$, Carolina Quintana ${ }^{4}$ \& Roger D. \\ Sepúlveda ${ }^{5}$
}

\begin{abstract}
It is critical to understand how to accommodate the 'resilience thinking' approach in city planning, in order for urban environments to adapt to extreme natural events. This study explored from both a conceptual and applied perspective, whether or not the resilience thinking approach has been adressed in urban planning, using Mehuin, Chile, as a case study. The methodology involved a qualitative review of planning tools, in orden to analyze the extent to which urban resilience attributes (e.g. diversity and redundancy) are addressed in Mehuin's planning, documents, along with a quantitative evaluation of resilience dimensions (i.e. physical, environmental and social) for Mehuin's urban environment. Our findings indicated that the environmental dimension has the greatest influence on the adaptive capacity of Mehuín; however, this is not addressed in the urban planning tools. These divergent results are further discussed with respect to the potential challenges that could arise in current planning science, as we know it.
\end{abstract}

Key words: Resilience thinking, urban planning, tsunami

\section{RESUMEN}

La comprensión de cómo acomodar el "pensamiento resiliente" en la planificación de ciudades es fundamental para la adaptación de los entornos urbanos a eventos naturales extremos. Este estudio explora si el pensamiento resiliente se ha abordado en la planificación urbana, tanto desde la perspectiva conceptual como de la aplicada, utilizando Mehuín, Chile, como caso de estudio. La metodología se basa en: Una revisión cualitativa de las herramientas de planificación para analizar en qué medida los atributos de la resiliencia urbana (por ejemplo, la diversidad y la redundancia) se abordan en los documentos de planificación; y una evaluación cuantitativa de las dimensiones de la resiliencia del medio ambiente

\footnotetext{
1 We would like to acknowledge CONICYT Fondecyt Project $\mathrm{N}^{\circ} 1150137$ for funding this study and Ms. Mina Fallahzadegan for collaborating with data collection and analysis. Artículo recibido el 7 de marzo de 2016, aceptado el 12 de mayo de 2016 y corregido el 13 de junio de 2016.

2 Instituto de Ciencias Ambientales y Evolutivas Laboratorio de Paisaje y Resiliencia Urbana, Universidad Austral de Chile (Chile).

E-mail: paula.villagra@uach.cl
}

3 Escuela de Arquitectura, Universidad Diego Portales (Chile). E-mail: geraldine.herrmann@udp.cl

4 Laboratorio de Paisaje y Resiliencia Urbana, Universidad Austral de Chile (Chile).

E-mail: carolina.quintana@alumnos.uach.cl

5 Instituto de Ciencias Ambientales y Evolutivas, Universidad Austral de Chile (Chile).

E-mail: rogersepulveda@uach.cl 


\begin{abstract}
urbano de Mehuín (es decir, la física, ambiental y social). Los resultados muestran que la dimensión ambiental es la que más influye en la capacidad de adaptación de Mehuín; sin embargo, esta dimensión no se aborda en las herramientas de planificación urbana. Estos resultados divergentes se discuten adicionalmente con respecto a los posibles retos que se plantean en la ciencia de la planificación actual tal como la conocemos.
\end{abstract}

Palabras clave: Pensamiento resiliente, planificación urbana, tsunami

The concept of resilience has been included in urban planning with the aim to address the challenges cities face from natural disasters. The 'resilience thinking' approach, introduced from ecology to the human environment by Walker \& Salt in 2006, has become the 'de facto' framework to improve preparation, response, and recovery after disaster at the community level (Cutter et al., 2014). Nonetheless, the misleading understanding of the concept in the urban planning realm commonly misguides the elaboration and implementation of strategies meant to ensure the resilience of communities. This is challenging considering that the concept of urban resilience is usually wrongly 'translated' into urban planning policies. This means that the misunderstanding of urban resilience leads to its incorrect conceptualization and/or implementation.

Resilience is the ability of a system to experience unexpected and extreme changes without crossing the threshold into a different system regime. In other words, it is the ability of a system to absorb disturbance and reorganize after change in order to retain the same function, structure, identity, and feedback capability (Walker et al., 2004). Resilience does not mean the elimination or the avoidance of disturbance. In the resilience thinking approach, disturbances such as earthquakes and tsunamis are part of systems just as is the human community; rather than avoid disturbances, we need to learn to adapt and plan for them. In urban environments, resilience refers to the ability of individuals, communities, institutions, businesses and systems within a city to survive, adapt, and grow regardless of who experiences chronic stress (Rockefeller Foundation, 2015). Resilience influences how planning should be organized for innovative transformations (Davoudi et al., 2012), however resilience planning requires the ability to think and prepare for successfully adapting to existing or potential adverse events (Cutter et al., 2014).
The resilience thinking approach of Walker \& Salt (2006) has influenced various scholars' thoughts related to planning. In order to regulate human communities, it has been agreed upon that urban planning should include seven resilience attributes (Norris et al., 2008; Allan \& Bryant, 2011; Ahern, 2011). These are: "Diversity", or having different options for adapting to a wide range of circumstances; "redundancy", or having multiple elements/components that provide similar functions in the event that others fail; "multi-functionality", to support response diversity required after a disaster; "modularity", for allowing individual modules to keep functioning when loosely linked modules fails; "multi-scale network and connectivity", to building resilient networks through redundant circuitry; "overlap in governance", which refers to redundancy in governance structures; and "adaptability with innovation", to encourage learning and experimentation in order to develop rules and embrace change at local scales.

Furthermore, when resilience is applied in a community, the resilience thinking approach encourages actions that address the community's multi-dimensionality; these dimensions, in turn, should be reflected in the planning of communities if the aim is to build resiliency (Vale \& Campanella, 2005; Cutter et al., 2014). Current resilient models have called the resilience dimensions as resilient capitals and resilient resources (Norris et al., 2008; Renschler et al., 2010; Cutter et al., 2014) suggesting that they are a set of goods, strategies, policies, and/or built and natural aspects that provide insight on the many variables that affect community resilience, positively or otherwise. Within the context of urban planning, we can acknowledge three broad resilience dimensions: The physical, environmental, and social dimensions. The physical dimension refers to the characteristics of urban morphology that affect the adaptive capacity of cities; among others, 
this includes population density, the amount of open space, built infrastructure useful for shelter, and the distance to and the amount of evacuation routes. Urban areas with high population densities and long distances to evacuation routes are less resilient (Cutter et al., 2008; Norris et al., 2008) than urban areas that have more open spaces, with built public infrastructure in safe areas, and with more evacuation routes per inhabitants (Chou et al., 2013; Villagra et al., 2014). The environmental dimension refers to the characteristics or natural systems that provide advantages for survival after disaster such as for provisions, mitigation, and regulation. For example, wide coastal forests reduce the intensity of tsunamis, and this, in turn, improves resilience (Forbes \& Broadhead, 2007). Conversely, increased distance to water, food, and wood resources decreases resilience (Millennium Ecosystem Assessment, 2005). Finally, the social dimension refers to the characteristics of communities including the percentage of people living in poverty, the amount of the population with special needs, and participation in and the number of civic and emergency organizations. Subsequently, a community is less resilient if it has a large percentage of people living in poverty and many people with special needs (Cutter et al., 2014). On the other hand, increased participation in community groups and a large amount of community and emergency organizations per number of inhabitants confer more resilience (Chou et al., 2013; Cutter et al., 2014).

In order to guide resilience planning, the resilience thinking approach encourages the inclusion of the seven resilience attributes in planning documents. All of these attributes do not need to be considered in only one policy; rather, the set of documents that comprises the planning instruments of the community should address them to the best extent possible. Similarly, all three resilience dimensions should be addressed in urban planning in order to enhance community resilience.

In Chile, the concept of resilience was introduced to the urban planning realm after the 2010 earthquake and tsunami (Mw8.8) which destroyed a large area of the coastal territory. Long before, in 2005, the Chilean government had signed the Hyogo Framework of Action (ISDR, 2005), committing, among other things, to build resilient communities. However, it was not until after the catastrophic event of 2010, when urban planners, policy makers, and urban designers began to consider resilience in the urban environment. Particularly along the coast, reconstruction and anti-tsunami coastal planning has taken an engineering rather than a resilience approach. The approach implemented mainly focuses on anti-tsunami engineering solutions such as coastal walls and mitigation parks (Herrmann, 2015). Examples of this are the Housing Approach in 1960 developed after the Mw 9.5 earthquake and tsunami in southern Chile (Aliste \& Perez, 2013) and the PRBC18 Master Plan in 2010 elaborated as a response to the Mw 8.8 event (GSAPP et al., 2015). These planning measures are nonbinding and have been developed in a weak national regulatory framework. Additionally, these measures have not had any influence on policy or planning decisions as they were developed in a context of a consultative participation (Herrmann, 2015). Until today, it remains unclear whether or not current urban planning strategies are in line with the resilience thinking approach that encourages planning with a multidimensional perspective and that considers resilience attributes.

This study aims to explore this issue by asking: To what extent do urban planning tools address the resilience approach in coastal communities? This study uses the town of Mehuín in southern Chile as a case study; since the 2010 earthquake and tsunami, this region has been under an imminent tsunami hazard (Lorito et al., 2011). Accordingly, the objectives are: First, to determine if resilience attributes are addressed in the planning tools used to regulate Mehuín; and second, to evaluate the resilience dimensions of Mehuín's urban environment to determine if the urban environment contributes to the city's resilience to future tsunamis. Figure $\mathrm{N}^{\circ} 1$ illustrates the model of study indicating that the outcomes can be used to provide feedback for the urban planning of Mehuín. Furthermore, from a resilience thinking approach, we expect to contribute to the emerging conceptual and applied resilience planning framework in Chile. 
Figure $\mathrm{N}^{\circ} 1$

Model of study

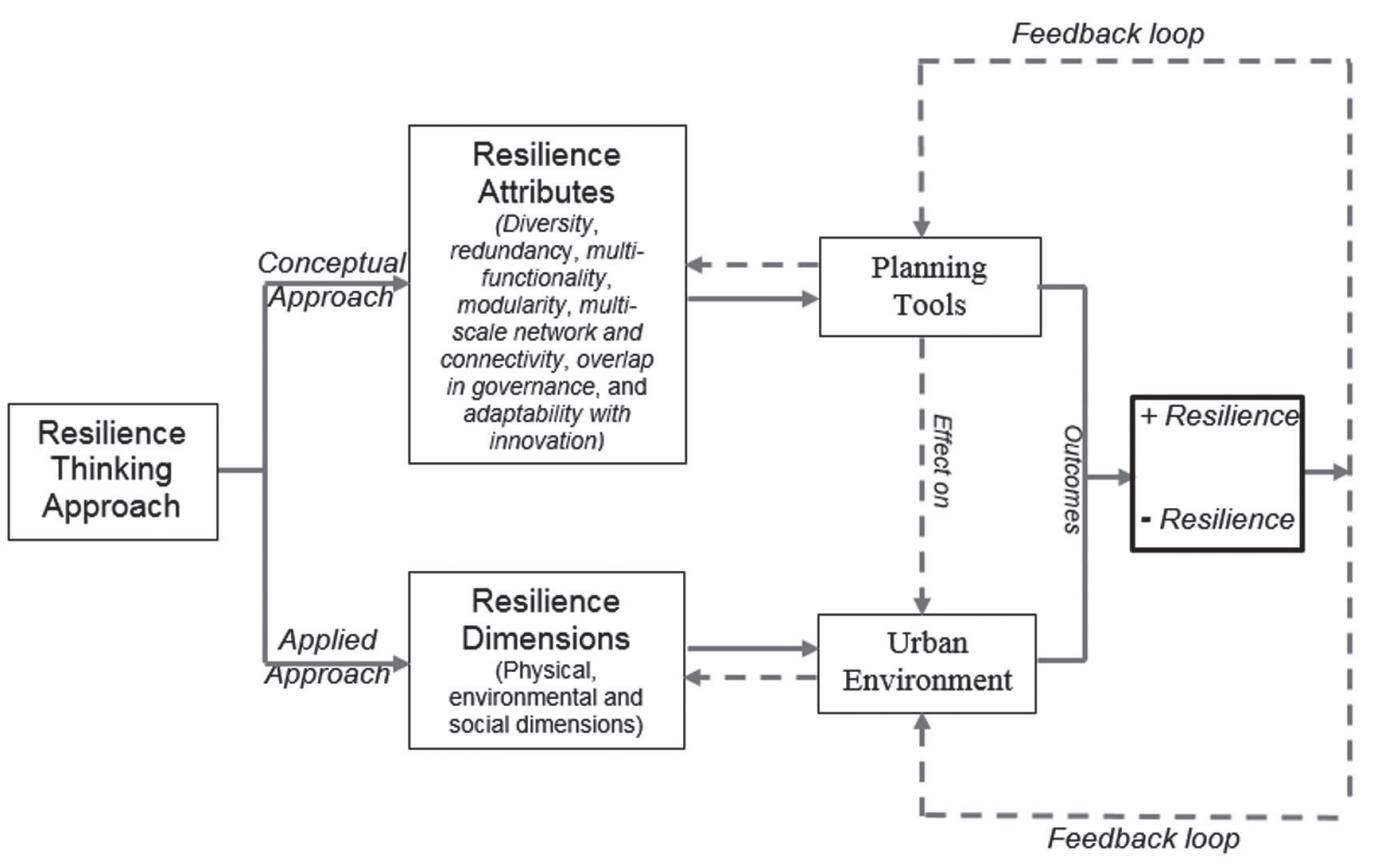

Source: Own elaboration.

\section{Methodology}

Research methods were chosen to analyze the different types of data (Silverman \& Marvasti, 2008). Since this study includes the exploration of nominal (found in planning documents) and ordinal data (to measure resilience variables), the methodology includes a mixed qualitative and quantitative approach to study the case of Mehuín.

Mehuín is a small coastal town in southern Chile (Comuna de Mariquina, Región de Los Ríos) with a population of approximately 1135 inhabitants (INE, 2005). Mehuín is located at the mouth of the Lingue River in a narrow coastal plain, adjacent to the coastal mountains (Cordillera de la Costa) that reach up to 200 meters. Mehuín, lying from 5 to up to twenty meters above sea level, is a linear settlement which runs parallel to the coast. Its main economic activities are fishing and tourism; Mehuín receives a large amount of visitors during the summer. It should be noted that Mehuín is a poor and marginalized community: $23.2 \%$ of Mehuín's population is indigenous (according to Census, 2002) and $19.4 \%$ is considered to be poor (CASEN, 2009; 2011). The majority of the population has not obtained higher education and unemployment is high. Mehuín can be clearly divided into five study areas, each with distinct character, urban composition, and geography: Mehuín Bajo (rural indigenous area), Mehuín Caleta (central urban, permanent residential area along the river), Balneario (urban, mixed permanent and temporary residential area along the beach), Pichicuyín (rural, mixed permanent and temporary residential area on a steep slope) and Mississippi (urban residential area on a steep slope) (Figure $\mathrm{N}^{\circ} 2$ ). 
Figure $\mathrm{N}^{\circ} 2$

Study areas in Mehuín, Chile

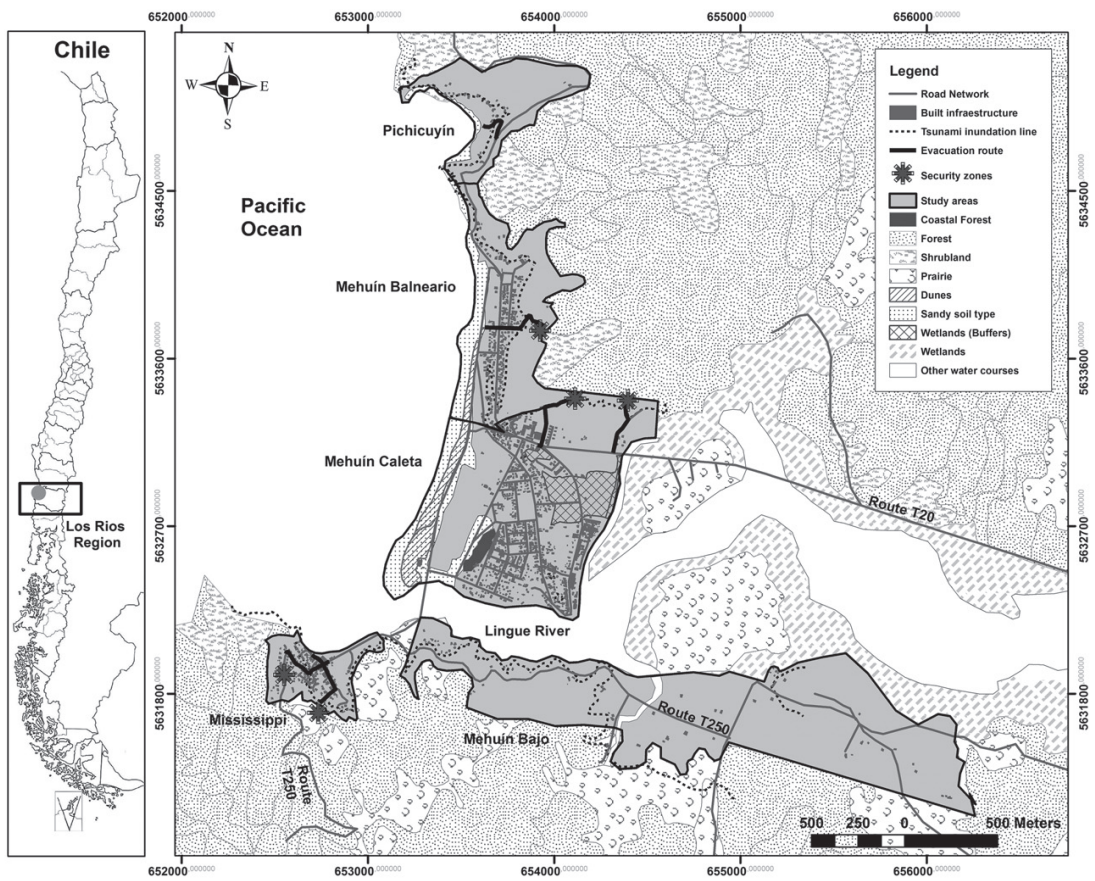

Source: Own elaboration with information about evacuation routes, safe zones, and tsunami inundation areas provided by the National Emergency Organization (ONEMI) and the Regional Government (GORE).

\section{The qualitative study of planning tools}

To determine if Mehuín's planning tools incorporate resilience attributes, we used a qualitative approach adapted from grounded theory and content analysis. Texts and maps comprise the study data. These include the Map of Civil Protection against Tsunamis (ONEMI, 2013), the Action Plan in case of Tsunamis and Earthquakes (Municipality of Mariquina, unpublished), the Regional Emergency Plan (ONEMI, 2012) and the Communal Regulating Plan (Municipality of Mariquina, 2015). The latter includes the Explanatory Memorandum and Land-use, Density and Road Network maps. While the first three planning documents were specifically developed to manage emergencies, the Communal Regulating Plan - which is currently being developed- is the main statutory urban planning tool at the local level. This plan can define street hierarchies, public services, land use through zoning plans (including zones for physical expansion) as well as protection zones and hazard zones. It should be highlighted that the Communal Regulating Plan is a binding planning tool. Building permits will be permitted by the municipality only if construction plans comply with usage regulations and standards set out for each zone; non-compliance will be sanctioned by the local government through fines. ${ }^{6}$

Each of these planning documents was analyzed and coded into the seven resilience attributes described in the introduction. The attributes include: Diversity, redundancy, multi-functionality, modularity, degree of

6 Communal Regulating Plans are developed by each municipality and have to be approved by the Communal Council, the Regional Ministerial Secretariats (Secretaría Regional Ministerial de Vivienda y Urbanismo/Seremi MINVU), the Regional Council, and they require public consultation with the community. 
multi-scale network and connectivity, overlap in governance and adaptability with innovation. The analysis of the seven attributes was conducted by two researchers with knowledge in resilience thinking applied to urban environments. This analysis involved coding the texts and maps of the planning tools. Complementarily, field visits were conducted to clarify aspects that were not well defined in the documents. The frequency of mention of each resilience attribute was used to determine if the planning tools address resiliency or not. In order to give examples of how the resilience attributes are understood in a planning context, Table $\mathrm{N}^{\circ} 1$ shows examples of the aspects of each planning tool that refer to each of the resilience attributes. For instance, references to Diversity were found in the Action Plan in the Case of Tsunamis and Earthquakes, in the Regional Emergency Plan and in the Communal Regulating Plan. Of the examples given, five aspects were found to positively contribute to the diversity resilience attribute and one aspect contributes negatively. The entire analysis of the attributes resulted in large tables, which are not shown here because the results are well summarized and illustrated as percentages and pie charts in later sections of this manuscript. The total frequency of mention of resilience attributes was used to determine the overall contribution of the urban planning tools to urban resilience. The coding process also involved to determine which aspects have a positive effect and which have a negative effect on resilience. This approach allowed us to identify which plan contributes to which specific attribute, which attributes are addressed by various tools, what attributes are not addressed, as well as the overall contribution of the planning tools to resiliency.

Table $N^{\circ} 1$

Example of the interpretation of the resilience attributes with respect to planning tools

\begin{tabular}{|c|c|c|c|c|}
\hline \multirow{2}{*}{$\begin{array}{l}\text { Resilience } \\
\text { Attributes }\end{array}$} & \multicolumn{4}{|c|}{ Planning Tools } \\
\hline & $\begin{array}{l}\text { Map of Civ- } \\
\text { il Protection } \\
\text { against Tsuna- } \\
\text { mis } \\
(\mathrm{O} \text { E M I, } \\
2013)\end{array}$ & $\begin{array}{l}\text { Action Plan in the } \\
\text { Case of Tsunamis } \\
\text { and Earthquakes } \\
\text { (Municipalidad de } \\
\text { Mariquina, unpub- } \\
\text { lished) }\end{array}$ & $\begin{array}{l}\text { Regional Emergency } \\
\text { Plan } \\
\text { (ONEMI, 2012) }\end{array}$ & $\begin{array}{l}\text { Communal Regu- } \\
\text { lating Plan } \\
\text { (Municipalidad de } \\
\text { Mariquina, 2015) }\end{array}$ \\
\hline \multirow{2}{*}{ Diversity } & & $\begin{array}{l}\text { (+) The navy and } \\
\text { the air force support } \\
\text { evacuation, diversi- } \\
\text { fying the options for } \\
\text { evacuation (18) }\end{array}$ & $\begin{array}{l}\text { (+) Different modes } \\
\text { of communication } \\
\text { (e-mail, telephone, } \\
\text { cell-phone and satel- } \\
\text { lite phone) are used for } \\
\text { communication among } \\
\text { organizations during an } \\
\text { emergency (30) }\end{array}$ & $\begin{array}{l}\text { (+) The bridge over } \\
\text { the Lingue River } \\
\text { provides an alter- } \\
\text { native for connect- } \\
\text { ing the neighbor- } \\
\text { hoods of Mehuín } \\
(118)\end{array}$ \\
\hline & & $\begin{array}{l}\text { (+) The local radio } \\
\text { provides an alter- } \\
\text { native option for } \\
\text { communication in } \\
\text { case of damage to } \\
\text { the cell-phone net- } \\
\text { work }(10)\end{array}$ & $\begin{array}{l}\text { (+) Considering the lo- } \\
\text { cation and arrival time } \\
\text { of the tsunami, the } \\
\text { navy coordinates the } \\
\text { evacuation with ships } \\
\text { varying in size and per- } \\
\text { formance in different } \\
\text { water conditions (168) }\end{array}$ & $\begin{array}{l}\text { (-) Building stan- } \\
\text { dards of residen- } \\
\text { tial areas located } \\
\text { in dune activation } \\
\text { zones and estuari- } \\
\text { ne flood risk zones } \\
\text { are the same as in } \\
\text { other non-risk zo- } \\
\text { nes (Map) }\end{array}$ \\
\hline
\end{tabular}




\begin{tabular}{|c|c|c|c|c|}
\hline \multirow[b]{2}{*}{$\begin{array}{l}\mathrm{R} \text { e d u n - } \\
\text { dancy }\end{array}$} & $\begin{array}{l}\text { (+) Three alter- } \\
\text { native evacua- } \\
\text { tion routes are } \\
\text { proposed for } \\
\text { Mehuín and } \\
\text { two are pro- } \\
\text { posed for Mis- } \\
\text { sissippi (1) }\end{array}$ & $\begin{array}{l}\text { (+) More than three } \\
\text { people are trained } \\
\text { to undertake the } \\
\text { role of regional of- } \\
\text { ficers in the case of } \\
\text { tsunamis }(15-16)\end{array}$ & $\begin{array}{l}\text { (+) Various people are } \\
\text { trained to give the tsu- } \\
\text { nami warning in case } \\
\text { the person responsible } \\
\text { fails }(30)\end{array}$ & $\begin{array}{l}\text { (+) The widening } \\
\text { of roads and the } \\
\text { construction of } \\
\text { others improve ac- } \\
\text { cessibility between } \\
\text { neighborhoods } \\
\text { and main evacua- } \\
\text { tion routes (30) }\end{array}$ \\
\hline & $\begin{array}{l}(-) \text { Lack of } \\
\text { an alterna- } \\
\text { tive evacua- } \\
\text { tion route for } \\
\text { Cheuque (1) }\end{array}$ & $\begin{array}{l}\text { (-) Only one tem- } \\
\text { porary shelter is de- } \\
\text { fined for the town } \\
\text { (The Yeco School) } \\
(22)\end{array}$ & $\begin{array}{l}\text { (+) Three locations are } \\
\text { identified as potential } \\
\text { temporary shelters af- } \\
\text { ter a tsunami: The Yeco } \\
\text { School for } 80 \text { people; } \\
\text { the San Luis de Alba } \\
\text { High School for } 120 \\
\text { people; and the Mu- } \\
\text { nicipal Gym for } 120 \\
\text { people }(217)\end{array}$ & \\
\hline \multirow{2}{*}{$\begin{array}{l}\text { M u I t i - } \\
\text { functiona- } \\
\text { lity }\end{array}$} & $\begin{array}{l}\text { (+) Some eva- } \\
\text { cuation routes } \\
\text { are also public } \\
\text { roads which } \\
\text { people use in } \\
\text { their daily life } \\
\text { for transporta- } \\
\text { tion (Field vi- } \\
\text { sit) }\end{array}$ & $\begin{array}{l}\text { (+) The Yeco School } \\
\text { is used as a school } \\
\text { for day to day life } \\
\text { and as a shelter af- } \\
\text { ter a tsunami (22) }\end{array}$ & $\begin{array}{l}\text { (+) Schools can be } \\
\text { used as shelters and } \\
\text { hospitals after a tsuna- } \\
\text { mi, only if the Regional } \\
\text { Secretary of Education } \\
\text { approves it (131) }\end{array}$ & $\begin{array}{l}\text { (+) Roads within } \\
\text { residential areas } \\
\text { and with green } \\
\text { bands can be used } \\
\text { as meeting points } \\
\text { during an emer- } \\
\text { gency (Map) }\end{array}$ \\
\hline & $\begin{array}{l}\text { (-) Safe zones } \\
\text { are small lef- } \\
\text { tover spaces } \\
\text { on a steep } \\
\text { slope outside } \\
\text { the urban limit } \\
\text { (Field visit) }\end{array}$ & $\begin{array}{l}\text { (+) The main plaza } \\
\text { of Mehuín can be } \\
\text { used as an emer- } \\
\text { gency control area } \\
\text { by the army in case } \\
\text { of an emergency } \\
(17)\end{array}$ & & \\
\hline $\begin{array}{l}\text { Modula- } \\
\text { rity }\end{array}$ & & & $\begin{array}{l}\text { (+) Standardizing and } \\
\text { formalizing emergen- } \\
\text { cy responses are the } \\
\text { main priorities of the } \\
\text { Regional Emergency } \\
\text { Plan (34) }\end{array}$ & \\
\hline \multirow{2}{*}{$\begin{array}{l}\text { Multi-sca- } \\
\text { le network } \\
\text { and con- } \\
\text { nectivity }\end{array}$} & $\begin{array}{l}\text { (-) Safe zones } \\
\text { are isolated } \\
\text { areas that are } \\
\text { not interlinked } \\
\text { (Field visit) }\end{array}$ & & $\begin{array}{l}\text { (+) One of the objec- } \\
\text { tives of this tool is to } \\
\text { normalize and coor- } \\
\text { dinate the communi- } \\
\text { cation system for an } \\
\text { appropriate multi- sec- } \\
\text { tor response in case of } \\
\text { emergency }(34)\end{array}$ & $\begin{array}{l}\text { (-) The road con- } \\
\text { necting San Jose } \\
\text { de Mariquina to } \\
\text { Mehuín is located } \\
\text { in a tsunami risk } \\
\text { zone which threa- } \\
\text { tens connectivity } \\
\text { (Map) }\end{array}$ \\
\hline & & & $\begin{array}{l}\text { (+) The health network } \\
\text { during an emergency is } \\
\text { formed by the Regional } \\
\text { Secretary of Health, the } \\
\text { Red Cross and the Civil } \\
\text { Defense (138) }\end{array}$ & $\begin{array}{l}\text { (-) Mississippi and } \\
\text { Cheuque are isola- } \\
\text { ted areas, linked to } \\
\text { Mehuín only to the } \\
\text { north and by the } \\
\text { bridge (Map) }\end{array}$ \\
\hline
\end{tabular}




\begin{tabular}{|c|c|c|c|}
\hline \multirow[b]{2}{*}{$\begin{array}{l}\text { Overlap in } \\
\text { governan- } \\
\text { ce }\end{array}$} & $\begin{array}{l}\text { (+) Coordination } \\
\text { between the natio- } \\
\text { nal and regional } \\
\text { COE is clearly defi- } \\
\text { ned }(16-20)\end{array}$ & $\begin{array}{l}(+) \text { In the case of a } \\
\text { Tsunami Red Alert, the } \\
\text { coordination among } \\
\text { the Regional COE, the } \\
\text { Community Responsi- } \\
\text { ble for Civil Protection, } \\
\text { Police, and Firefighters } \\
\text { is well defined (29) }\end{array}$ & \\
\hline & $\begin{array}{l}(+) \text { In the case of } \\
\text { road damage after } \\
\text { an emergency, the } \\
\text { Regional Secretary } \\
\text { of Transportation } \\
\text { and Telecommu- } \\
\text { nication and the } \\
\text { Ministry of Public } \\
\text { Works (MOP) are } \\
\text { both responsible for } \\
\text { informing the com- } \\
\text { munity (17) }\end{array}$ & $\begin{array}{l}\text { (-) If more funds are } \\
\text { demanded than those } \\
\text { available in the local } \\
\text { municipality, the fund } \\
\text { for emergency supplies } \\
\text { is requested from cen- } \\
\text { tral headquarters in } \\
\text { Santiago (32) }\end{array}$ & \\
\hline \multirow{2}{*}{$\begin{array}{l}\text { Adaptabi- } \\
\text { lity with } \\
\text { innovation }\end{array}$} & $\begin{array}{l}\text { (+) The emergency } \\
\text { response process } \\
\text { includes, as one of } \\
\text { the steps, the refor- } \\
\text { mulation and read- } \\
\text { justment of opera- } \\
\text { tions in case of an } \\
\text { unexpected event } \\
\text { (20) }\end{array}$ & $\begin{array}{l}\text { (+) Schools designat- } \\
\text { ed for emergency shel- } \\
\text { ters can be replaced } \\
\text { by others (the Regional } \\
\text { Secretary of Education) } \\
\text { in the event that the } \\
\text { school was damaged } \\
\text { following the event } \\
\text { (132) }\end{array}$ & $\begin{array}{l}\text { (-) The neighbor- } \\
\text { hoods which are } \\
\text { furthest from the } \\
\text { safe zones have } \\
\text { the narrowest road } \\
\text { network (Map) }\end{array}$ \\
\hline & & $\begin{array}{l}\text { (+) Designing, upda- } \\
\text { ting, and practicing the } \\
\text { evacuation plans are } \\
\text { defined as part of the } \\
\text { general procedures for } \\
\text { improving evacuation } \\
(123)\end{array}$ & \\
\hline
\end{tabular}

Source: Own elaboration.

Note: Up to two aspects addressing resilience attributes are provided for each planning tool in order to give examples of how the resilience attributes are understood in the planning context. In cases where the planning tool does not address resiliency, the cell was left blank. Aspects of the planning tools that add to resilience attributes are marked with a positive sign; the opposite is indicated with a negative sign. The information in parenthesis at the end of each aspect indicates the page number where the information was found; for some aspects, the note in parenthesis refers to the map part of the document or to field visits.

The quantitative study of the urban environment

A quantitative approach was used to measure variables of resilience for the urban environment of Mehuín. Then, we explored the extent to which each resilience dimension contributes to resiliency. For this, variables associated with the physical, social, and environmental dimensions described in the introduction were measured for each study area (See Table
$N^{\circ}$ 2). These measurements were made using databases of the Municipality of Mariquina, National Forest Coorporation (CONAF) and the National Emergency Organization (ONEMI). Specifically, geomorphological and land use units were determined based on the coverage provided by CONAF (2006); these measurements were supplemented and corrected with Google Earth and with the information gathered during field visits. This analysis was performed using ArcGIS 10.3.1 and the measure 
tool; with this, Euclidean distances between the community and provision resources, evacuation routes, and open and built spaces were calculated. After a tsunami strikes, it is expected that most of the urban grid and built features would disappear in these coastal towns as this has previously happened following natural disasters in Chile (e.g. Dichato). For this reason, Euclidean distances were calculated. Measurements of the variables linked to the social dimension were calculated using local and national free access databases of the National Institute of Statistics (INE), National Socio-economic Characterization Survey (CASEN), and the Municipality of Mariquina.

To analyze the data, a multivariable analysis was undertaken using twenty-one variables that address the physical, environmental, and social aspects of resilience. Principal Component Analysis (PCA) is an unconstrained multidimensional metric scaling ordination that extracts the major variance components of the multivariate dataset in order to reduce the dimensionality of the original variables; this is done by minimizing the residuals of the multivariate data through the use of matrix metrics (Quinn \& Keough, 2002). For this, we used correlated matrices because the variables were measured in different units and/or the magnitude of the variables was not comparable. Therefore, the raw data of each variable were normalized using $\mathrm{z}=\left(x_{i}-\mu\right) /$, where $x_{i}$ is the data value, $\mu$ is the mean, and is the standard deviation. Following this, the data were comparable and had standardized normal distributions where $\mu=0$ and $2=1$. With the normalized variables, Principal Component Analyses (PCA) were performed for all of the dimensions and for each dimension (i.e., physical, environmental, and social) separately. Finally, to analyze whether there was a positive or negative relationship between the study areas (i.e., Mehuín Caleta, Mehuín Balneario, Mehuín Bajo, Mississippi, and Pichicuyín) and resilience, eigenvector analyses were conducted (i.e., magnitudes: -1 < eigenvectors < $+1)$. The variables that did not vary between the study areas (i.e., variables measured at the community level such as social capital-civic participation, tsunami drills, percentage of the population living in poverty, and percentage of the population with special needs) were not included in the PCA ordinations. The results are illustrated in bi-plot models using the first two principal components, which explained more than $80 \%$ of the total variance. Particularly for a PCA based on correlated matrices, the eigenvalues are equivalent to the number of variables that account for the variance explained in each principal component; this facilitates the interpretation of the orthogonal components (for details see Quinn \& Keough, 2002).

Table $\mathrm{N}^{\circ} 2$

Variables included in the PCA analysis

\begin{tabular}{|c|c|c|c|c|}
\hline Dimension & Variable name & $\begin{array}{l}\text { Acron- } \\
\text { ym }\end{array}$ & Measurement & Data source \\
\hline \multirow{7}{*}{ Physical } & Balance Index & $\mathrm{BI}$ & $\begin{array}{l}\sum \mathrm{m} 2 \text { unbuilt area / } \\
\sum \mathrm{m} 2 \text { built area }\end{array}$ & $\begin{array}{l}\text { Municipality of } \\
\text { Mariquina, } 2015\end{array}$ \\
\hline & $\begin{array}{l}\text { Temporary Open Space } \\
\text { System }\end{array}$ & OSS & $\sum \mathrm{m} 2 /$ inhabitants & $\begin{array}{l}\text { INE, } 2002 ; \text { IDE } \\
\text { Chile, } 2014\end{array}$ \\
\hline & $\begin{array}{l}\text { Diversity Index - Open Spa- } \\
\text { ce System }\end{array}$ & OSSDI & Shannon-Wiener & ONEMI, 2012 \\
\hline & Population Density & PD & Inhabitants / ha & $\begin{array}{l}\text { INE, } 2002 ; \text { IDE } \\
\text { Chile, } 2014\end{array}$ \\
\hline & Evacuation Route-Index & ERI & $\begin{array}{l}\sum \text { evacuation routes } \\
/ \text { (inhabitants/100) }\end{array}$ & ONEMI, 2013 \\
\hline & Evacuation Route Distance & ERD & Meters & ONEMI, 2013 \\
\hline & Community Facility Index & $\mathrm{CFI}$ & $\sum \mathrm{m} 2 /$ inhabitants & $\begin{array}{l}\text { INE, } 2002 ; \text { IDE } \\
\text { Chile, } 2014\end{array}$ \\
\hline
\end{tabular}




\begin{tabular}{|c|c|c|c|c|}
\hline \multirow{8}{*}{$\begin{array}{l}\text { Environmen- } \\
\text { tal }\end{array}$} & Sandy Soil Type & ST & $\begin{array}{l}\text { Square meters / area } \\
\text { of study site }\end{array}$ & CONAF, 2006 \\
\hline & Water Provision Distance & WPD & $\begin{array}{l}\text { Meters to water bo- } \\
\text { dies }\end{array}$ & CONAF, 2006 \\
\hline & Food Provision Distance & FPD & $\begin{array}{l}\text { Meters to natural } \\
\text { food resources }\end{array}$ & CONAF, 2006 \\
\hline & $\begin{array}{l}\text { Fire Wood Provision Dis- } \\
\text { tance }\end{array}$ & FWPD & Meters to forests & CONAF, 2006 \\
\hline & Forest Buffer & FB & $\begin{array}{l}\text { Width of coastal fo- } \\
\text { rest }\end{array}$ & CONAF, 2006 \\
\hline & Natural Flood Buffer & NFB & $\%$ land in wetlands & CONAF, 2006 \\
\hline & Natural Dune Buffer-Height & NDBh & $\begin{array}{l}\text { Predominat height of } \\
\text { semi-estabilized and } \\
\text { estabilized dunes }\end{array}$ & $\begin{array}{l}\text { Authors ellabora- } \\
\text { tion }\end{array}$ \\
\hline & Natural Dune Buffer-Cover & NDBC & $\begin{array}{l}\% \text { of vegetaion co- } \\
\text { ver of semi-estabili- } \\
\text { zed and estabilized } \\
\text { dunes }\end{array}$ & $\begin{array}{l}\text { Authors ellabora- } \\
\text { tion }\end{array}$ \\
\hline \multirow{6}{*}{ Social } & Population Poverty & PP & $\%$ & $\begin{array}{l}\text { CASEN } 2009- \\
2011 ; \text { INE } 2002\end{array}$ \\
\hline & $\begin{array}{l}\text { Social Capital-Civic Parti- } \\
\text { cipation }\end{array}$ & SCCP & $\%$ & CASEN 2009 \\
\hline & $\begin{array}{l}\text { Social Capital-Civic Orga- } \\
\text { nizations }\end{array}$ & SCCO & $\begin{array}{l}\text { Number of civic or- } \\
\text { ganization / } 1000\end{array}$ & $\begin{array}{l}\text { Municipalidad de } \\
\text { Mariquina, } 2015\end{array}$ \\
\hline & $\begin{array}{l}\text { Social Capital-Emergency } \\
\text { Organizations }\end{array}$ & SCEO & $\begin{array}{l}\text { Number of volun- } \\
\text { teers / } 1000\end{array}$ & $\begin{array}{l}\text { Municipalidad de } \\
\text { Mariquina, } 2015\end{array}$ \\
\hline & Tsunami Drills & TD & $\begin{array}{l}\text { Number between } \\
2010 \text { and } 2015\end{array}$ & ONEMI, 2012 \\
\hline & Special Needs Population & SNP & $\%$ & CASEN, 2013 \\
\hline
\end{tabular}

Source: Own elaboration.

Note: Variables were elaborated based on the work of Allan \& Bryant (2011), Chou et al. (2013), Cutter et al. (2014), Forbes \& Broadhead (2007), Millennium Ecosystem Assessment (2005), Norris et al. (2008) and Villagra et al. (2014).

\section{Contribution of planning tools to the resilience of Mehuín}

Although resilience itself is not directly mentioned in the documents, the analysis of the planning tools indicated, that the planning tools do address resiliency by considering actions that encompass all seven resilience attributes. Considering all of the tools together, reference to resilience attributes was made 48 times. Of these references, 72.9\% include aspects that positively contribute to resilience, and $27.1 \%$ negatively contribute to resilience.

With respect to the positive references to resilience, Figure $\mathrm{N}^{0} 3$ shows that the planning tools mostly address issues related to diversity (22\%), redundancy (29\%) and multi-functionality (26\%). By looking at the results of each individual plan, it is clear that the different plans do not refer to all attributes in the same manner. The Regional Emergency 
Plan is the most comprehensive of all, because it addresses all attributes with a focus on the multi-scale network and connectivity $(25 \%)$ and overlap in governance (25\%). This result was not surprising because this plan is the only planning tool that comprises a wide range of actions related to the management of the territory at the regional scale after a disaster. For example, this planning tool regulates the Emergency Operations Committee (COE) including what organizations participate and their roles following a disaster. The Regional Emergency Plan encourages: different modes of communication (diversity); the allocation of different people to inform the public about potential natural hazard (redundancy); the use of different schools for temporary shelter (multi-functionality); permanent communication between ONEMI and various emergency organizations at national and regional levels (multiscale network and connectivity); coordination among different emergency organizations to fulfill the same duties after a disaster (overlap in governance); and a regular plan to test, update, and modify the emergency and evacuation according to the results of said tests (adaptability with innovation). This plan is followed by the Action Plan in Case of a Tsunami and/or Earthquake, which is similar to the Regional Emergency Plan but functions at the communal scale; only the modularity and multi-scale network and connectivity attributes are not addressed here.

In contrast, The Map of Civil Protection against Tsunamis only addresses the redundancy and multi-functionality resilience attributes. As this tool only consists of a map which indicates the number and location of evacuation routes and safe zones (a total of 6 of each), it is not a surprise that this tool does not address all attributes of resilience.

One interesting result of the analysis was that the statutory Communal Regulating Plan, which was the one planning tool studied that does not relate to emergencies in particular, includes actions that promote resiliency. Specifically, this tool promotes the development of various open green areas of different sizes and types which contribute to the multi-functionality of the town. In the event of a disaster, these open spaces could provide refuge, resources, and other needs that arise after a catastrophe. In addition, this plan promotes the construction of a new bridge and roads that add to the connectivity among areas within Mehuín, between Mehuín, and with other major cities: thus, this plan also contributes to the diversity and redundancy of the network.

Figure $\mathrm{N}^{\circ} 3$

Positive contribution of the planning tools to the resilience of Mehuín

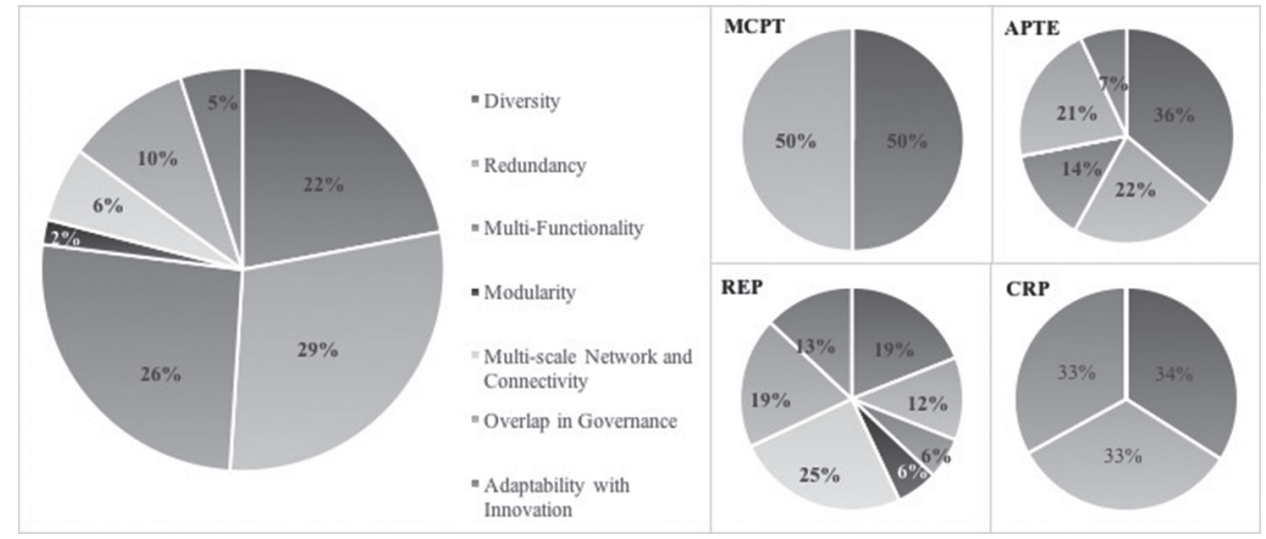

Source: Own elaboration.

Note: The chart to the left includes the frequency of references made to the resilience attributes in all of the planning tools. The charts to the right illustrate the frequency of references made by each planning tool. Frequencies are expressed in percentages. MCPT is the Map of Civil Protection against Tsunamis; APTE is the Action Plan in case of a Tsunami and Earthquake; REP is the Regional Emergency Plan; CRP is the Communal Regulating Plan. 
With respect to the negative references to resilience mentioned in the planning tools, Figure $\mathrm{N}^{0} 4$ shows that most of these references were categorized within the redundancy (29\%) and overlap in governance $(25 \%)$ resilience attributes. Negative references to modularity were not found during this analysis. The Regional Emergency Plan only includes negative references to overlap in governance. In page 32, it is indicated that "if the event is greater than the municipal level, the fund for emergency supplies should come from central headquarters in Santiago". This suggests that there is a gap with respect to the coordination of funding and in turn, decision making, which should be as timely and appropriate as possible after a disaster. Similarly, the Action Plan in case of Tsunamis and Earthquakes only includes negative references to redundancy; for example, there is just one temporary shelter defined in this action plan.
The negative references found in the Map of Civil Protection against Tsunamis refer to difficulties and questions that arise when using evacuation routes and zones. For example, some evacuation routes are on private land, and it is not clear to what extent this can be considered as multi-functional. In addition, the safe zones are currently secluded meeting points without infrastructure or links between them; this would affect connectivity after a disaster. Similarly, the main exit connecting the town to the east crosses a shallow river and to the north crosses an area prone to landslides. Should these exits become blocked, connectivity could be further compromised. Further to this, resilience diversity could be affected because the Communal Regulating Plan is considering building residential areas in key open green spaces in the periphery of the town, which could otherwise be used for large temporary infrastructure such as temporary hospitals.

Figure $\mathrm{N}^{\circ} 4$

Negative contribution of the planning tools to the resilience of Mehuín

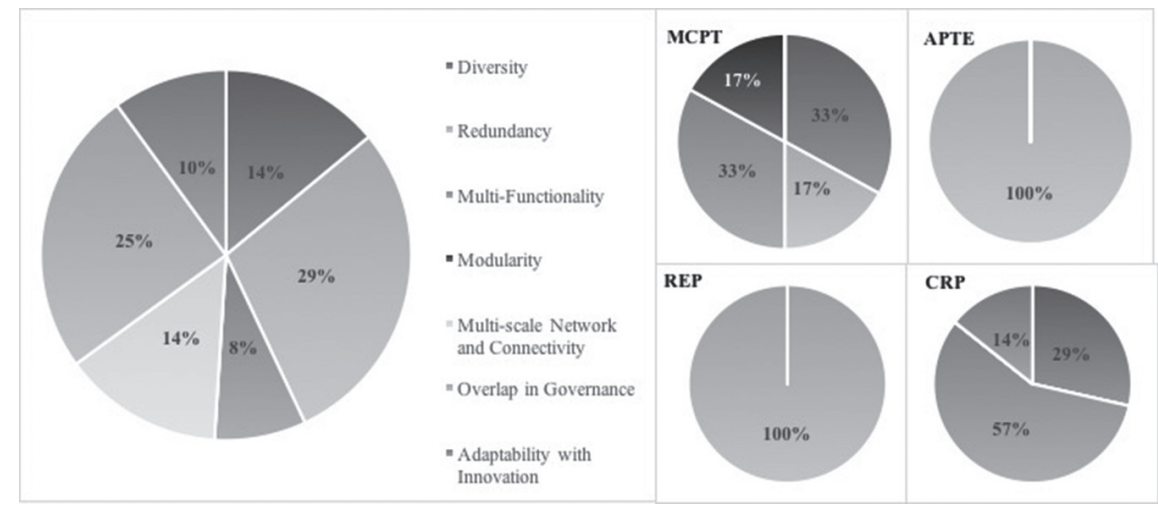

Source: Own elaboration.

Note: The chart to the left includes the frequency of references made to resilience attributes in all planning tools. The charts to the right illustrate the frequency of references made by each planning tool. Frequencies are expressed in percentages. MCPT is the Map of Civil Protection against Tsunamis; APTE is the Action Plan in case of Tsunamis and Earthquakes; REP is the Regional Emergency Plan; CRP is the Communal Regulating Plan.

\section{Resilience biplot models}

From the PCA results it was possible to determine which resilience variables and dimensions contribute the most to Mehuin's overall resilience and to the resilience of each of the five individual study areas. The PCA (Figure $\left.N^{\circ} 5 a\right)$ indicated that both the environmental and physical dimensions contribute the most to Mehuín's overall resilience. Nevertheless, the eigenvector analysis showed that the environmental variables best differentiated the 
study areas within Mehuín (see Table $N^{\circ} 3$ ). The social variables were not well separated in the PCA (the four social variables incorporated in the PCA were Percentage of Population Living in Poverty, Social Capital-Civic Participation, Percentage of the Population with Special Needs, and Amount of Tsunami Drills); therefore, the social dimension had the least effect on resilience. This does not mean that social variables are not relevant, but given the data, these variables were not as influential in determining Mehuín's resilience. Figure $N^{\circ} 5 a$ also shows that while the environmental dimension most influenced the resilience of Mehuín Balneario and Caleta Mehuín, the physical variables were more influential in determining the resilience of Mehuín Bajo and Pichicuyín. On the other hand, both the physical and environmental components equally contributed to Mississippi's resilience. Figures $\mathrm{N}^{\circ} 5 \mathrm{~b}, 5 \mathrm{c}$ and $5 \mathrm{~d}$ provide more information in order to understand the differences in the contribution of the variables to the resilience of the study areas.

Figure $\mathrm{N}^{\circ} 5$

Principal Component Analysis results
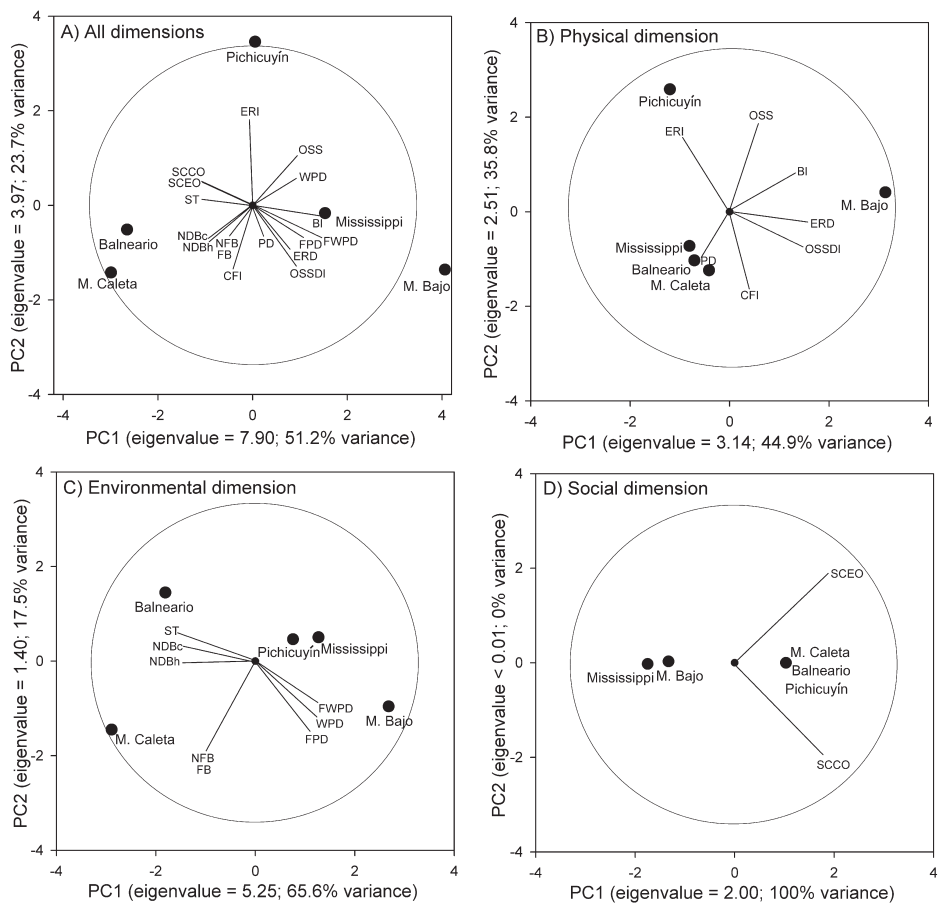

Source: Own elaboration.

Note: Principal Component Analyses were performed based on correlated matrices (i.e., normalized variables) to standardize the units of measurement of the variables. The higher the value of the variable the more positive effect that the variable had on resilience: Balance Index (BI), Temporal Open Space System (OSS), Diversity Index-Open Space System (OSSDI), Evacuation Route-Index (ERI), Community Facility Index (CFI), Forest Buffer (FB), Natural Flood Buffer (NFB), Natural Dune Buffer-Height (NDBh), Natural Dune Buffer-Cover (NDBc), Social Capital-Civic Organizations (SCCO) and Social Capital-Emergency Organizations (SCEO). In contrast, the higher the value of the variable the more negative effect that the variable had on resilience: Population Density (PD), Evacuation Route-Distance (ERD), Sandy Soil Type (ST), Water Provision Distance (WPD), Food Provision Distance (FPD) and Fire Wood Provision Distance (FWPD). Four social variables (i.e., Social Capital-Civic Participation (SCCP), Tsunami Drills (TD), Population Poverty (PP), and Special Needs Population (SNP)) were not included in the analyses because the magnitude of these variables had the same weight for all of the study areas. 
Table $\mathrm{N}^{\circ} 3$

Coefficients (eigenvectors) of the first two principal components generated from the multivariate variables for all dimensions

\begin{tabular}{|c|c|c|c|c|}
\hline Dimension & Variable name & Acronym & PC1 & PC2 \\
\hline \multirow{7}{*}{ Physical } & Balance Index & $\mathrm{BI}$ & 0.303 & -0.053 \\
\hline & Temporal Open Space System & OSS & 0.211 & 0.313 \\
\hline & $\begin{array}{l}\text { Diversity Index-Open Space } \\
\text { System }\end{array}$ & OSSDI & 0.239 & -0.336 \\
\hline & Population Density & PD & 0.040 & -0.115 \\
\hline & Evacuation Route-Index & ERI & -0.028 & 0.491 \\
\hline & Evacuation Route-Distance & ERD & 0.214 & -0.255 \\
\hline & Community Facility Index & $\mathrm{CFI}$ & -0.148 & -0.355 \\
\hline \multirow{8}{*}{ Environmental } & Sandy Soil Type & ST & -0.334 & 0.016 \\
\hline & Water Provision Distance & WPD & 0.239 & 0.217 \\
\hline & Food Provision Distance & FPD & 0.261 & -0.189 \\
\hline & Fire Wood Provision Distance & FWPD & 0.307 & -0.190 \\
\hline & Forest Buffer & $\mathrm{FB}$ & -0.192 & -0.197 \\
\hline & Natural Flood Buffer & NFB & -0.192 & -0.197 \\
\hline & Natural Dune Buffer-Height & NDBh & -0.296 & -0.219 \\
\hline & Natural Dune Buffer-Cover & NDBc & -0.294 & -0.211 \\
\hline \multirow{2}{*}{ Social } & $\begin{array}{l}\text { Social Capital-Civic Organi- } \\
\text { zations }\end{array}$ & $\mathrm{SCCO}$ & -0.283 & 0.163 \\
\hline & $\begin{array}{l}\text { Social Capital-Emergency Or- } \\
\text { ganizations }\end{array}$ & SCEO & -0.279 & 0.159 \\
\hline
\end{tabular}

Source: Own elaboration.

Note: The four social variables, Social Capital-Civic Participation (SCCP), Tsunami Drills (TD), Population Poverty (PP), and Special Needs Population (SNP)) were not included in analyses because the magnitude of the variables had the same weight for all of the study areas.

\section{The Physical Dimension}

Because Mehuín Balneario, Mississippi, and Mehuín Caleta cluster together based on the PCA of the physical variables (Figure $\mathrm{N}^{\circ}$ $5 b)$, the same physical variables equally affected the resilience of these study areas. These three study areas are located in the central part of the urban system and are highly affected by the variable population density (PD). Specifically, the data suggest that the high population density observed in the three areas had a negative effect on their resilience.
Temporary Open Space (OSS) lies opposite from PD on Figure No 5b. This reinforces the finding mentioned above because in these areas there are few useful open spaces that could be used in a disaster, likely due to the high population density in these areas.

On the other hand, Pichicuyín and Mehuín Bajo cluster independently from each other and from the other three study areas (Figure $\mathrm{N}^{\circ} 5 \mathrm{~b}$ ). This indicates that the resilience of these areas is affected by other variables. Mehuín Bajo was affected by the Balance 
Index (BI) and by the Distance to Evacuation Routes (ERD). Specifically, the BI of Mehuín Bajo includes low land use density, which positively contributes to post-disaster resilience. Furthermore, Mehuín Bajo has a long distance to evacuation routes which does not favor resilience. Pichicuyín, on the other hand, clusters with the Evacuation Route Index (ERI); the large amount of evacuation routes per capita from Pichicuyín positively contributes to its resilience. However, the lack of community facilities (CFI) in Pichicuyín negatively impacts its resilience. Pichicuyín and Mehuín Bajo are both located on the periphery of Mehuín (See Figure $\mathrm{N}^{\circ} 2$ ) and are currently being included in the Communal Regulating Plan. Hence, these areas are in the transition process of being defined as urban areas, whereas previously they were defined as rural. This could explain the results found here. As rural areas, the population density of these areas is lower and they have more open space to be used after a disaster. However, Pichicuyín and Mehuín Bajo have not been regulated by planning tools which address emergency issues in urban areas only. As a result, these areas currently lack appropriate tsunami evacuation and refuge plans.

\section{The Environmental Dimension}

Due to the separation of the study areas in the PCA of the environmental dimension, it can be seen that the study areas differ in terms of their environmental variables that influence their resilience capacity (Figure No 5c). Only Pichicuyín and Mississippi cluster together. The variables Natural Flood Buffer (NFB) and Forest Buffer (FB) lie on opposite sides of Pichicuyín and Mississippi, indicating the limited capacity of wetlands to mitigate the effects of a tsunami in these areas. This is likely due to the lack of coastal wetlands and forests between these study areas and the sea (Figure $\mathrm{N}^{\circ} 2$ ).

Mehuín Bajo, on the other hand, clusters with the water (WPD), food (FPD) and firewood (FWPD) provision variables. This indicates that the distance to these resources, once in a safe area, is higher than it would be for the other study areas. This suggests that Mehuín Bajo has increased resilience compared to the other study areas. Although Mehuín Bajo has ample agriculture and grazing lands near the housing areas, these areas are mostly below the tsunami inundation line making them unavailable for use after a tsunami. Mehuín Caleta moderately clusters with the buffer variables. Natural Flood Buffer (NFB), Forest Buffer (FB) and the Natural Dune Buffer (NDBh, NDBC) variables contribute to the resilience of this area. A system of wetlands surrounding Mehuín Caleta, as well as a system of semi-stabilized dunes between Mehuín Caleta and the sea add to the resilience of this area. Lastly, Mehuín Balneario clusters near the Natural Dune Buffer (NDBh, NDBc) variables. The dunes in Mehuín Balneario are the northward extension of the same dunes in Mehuín Caleta. However, Mehuín Balneario is also associated with the variable Soil Type (ST) indicating that the sandy beach between this area and the sea does not contribute to resilience. The beach is a mobile and very dynamic system that could be easily eroded by a tsunami; this in turn could have repercussions on the touristic, recreational, and ecological aspects of Mehuín Balneario.

\section{The Social Dimension}

The results of the social dimension PCA in Figure $N^{\circ} 5 d$, showed few differences among the study areas, and only two variables were influential on resilience. Mehuín Caleta, Mehuín Balneario, and Pichicuyín were moderately related to the social capital variables, including Social Capital-Civic Organizations (SCCO) and Social Capital-Emergency Organizations (SCEO). This indicates that in these areas the number of civic organizations (i.e. neighborhood associations, elderly clubs, farmers and fishermen associations, etc.) and the number of emergency agencies that assist these sectors (ranging from ONEMI at the regional level to firefighters and police at the local level), is greater accounting for population density (see the introduction to understand how these variables are measured) than in the other areas (Mehuín Bajo and Mississippi). Thus, social capital contributes to the resilience of Mehuín Caleta, Mehuín Balneario, and Pichicuyín. Interestingly enough, Mehuín Caleta, Mehuín Balneario and Pichicuyín are located to the north of the river and have direct road access to other major cities. On the other hand, Mehuín Bajo and Mississippi are located to the south of the river and are connected to other areas via waterways, a bridge, 
and unpaved roads, which can be affected after a tsunami limiting the accessibility to these areas. This partly explains why most of the emergency and civic organizations are located in the areas north of the river.

\section{Planning Tools and Urban Resilience}

The main finding presented here is the disparity in the results found between the study of the planning tools associated with Mehuín and the study of the urban environment of Mehuín. The analysis of the urban environment of Mehuín revealed that the environmental dimension, followed by the physical and social dimensions, most contributes to community resilience. However, the detailed revision of Mehuín's planning documents shows that the environmental dimension is scarcely being considered in urban planning.

Although the statutory Communal Regulating Plan promotes the development of various open green areas, thus contributing to the multi-functionality of the town by providing potential space for refuge, it also considers building new residential areas in key open green spaces at the periphery of the town. Furthermore, none of the planning documents mention the important role that coastal ecosystems and natural inundation buffers play in mitigating the impact of tsunamis and in providing basic resources to satisfy survival needs after a disaster. In fact, natural inundation buffers such as wetlands, dunes and forests are not currently protected by any statutory planning instrument at the regional or local level.

The Hyogo Framework of Action (ISDR, 2005) identified integrated natural resource management and land-use planning as an important tool for mitigating socio-natural disasters and for building community resilience. Maximizing the resiliency of poor communities in hazard prone coastal zones does not just require the planning of the physical dimension but also requires "ensuring communities have access to a diversity of ecosystem services" since ecosystems may significantly contribute to disaster risk reduction (Ingram \& Khazai, 2012: 388-369). It should be noted that enhancing the resilience of poor com- munities through 'natural infrastructure' is an opportunity to not only reduce disaster risks but also to provide additional benefits such as environmental and recreational services (Millennium Ecosystem Assessment, 2005). This has been acknowledged in various community resilience models (Norris et al., 2008; Renschler et al., 2010; Cutter et al., 2014), which consider aspects of natural resources for measuring resilience to disaster.

Urban planners should consider facilitating access to diverse ecosystem services in Mehuín, as well as for the entire Chilean coast which is characterized by a rich diversity of natural resources that have been largely overlooked in urban planning. In Mehuín, the natural resources outside of the urban area have not been regulated due to the limitations of the Communal Regulating Plan that functions only up to the urban border. Such ecosystem services, as was found in Mehuín, could include buffers to reduce the impact of tsunamis and provision services required for improving resilience.

It should be highlighted, that unfortunately in Chile there are no statutory planning instruments to regulate land located outside of urban areas. This is especially problematic for enhancing coastal resilience, since many relevant natural resources -for example, flood buffers such as wetlands or forests- are often located adjacent to coastal settlements but outside urban boundaries. As a consequence, in Chile tsunami inundation zones outside urban areas cannot be regulated in a binding way. In this sense, a national program to plan, regulate, and manage coastal areas could present an opportunity to integrate natural resource management and land-use planning in order to enhance community resilience. Although in Chile a National Commission for the Use of the Coastal Border (Comisión Nacional de Uso del Borde Costero) has been created as has a national coastal border zoning program, in fact, the coastal zone is regulated by multiple institutions (municipalities, Chilean Navy, Ministry of Public Works, etc.) which lack clear coordination (Herrmann, 2015). Other planning tools which could regulate buffer and provision services outside the urban area are the nonbinding Regional Plans of Territorial Regulation (PROT) and the statutory Intercommunal 
Plans. The Intercommunal Plan of the Coastal Border and River System of the Los Rios Region, which is currently under development, has the potential to address this issue. As other Intercommunal Plans developed in Chile, these spatial plans can designate, among others, green spaces and risk areas at intercommunal levels (Gobierno de Chile, 2015). However, and as mentioned above, rural areas outside of the urban boundary cannot currently be regulated by statutory regulations and are only subject to indicative zoning.

Integrated natural resource management and land-use planning is not only the duty of urban planners, but also is a task for ecologists. The role of ecosystem services in aiding recovery after a disaster is determined by the changes that the ecosystem itself faces. Hence, thorough landscape level assessments need to be undertaken to identify the mechanisms by which coastal ecosystems function, and how they can be altered by disturbance. Since ecosystems are dynamic, their effect on community resiliency can vary significantly throughout time (Ingram \& Khazai, 2012).

Contrary to that of the environmental dimension, the physical dimension is well considered in regional as well as local planning documents for Mehuín. The Regional Emergency Plan encourages the use of different schools for temporary shelter, and the Map of Civil Protection against Tsunamis highlights the location of evacuation routes and safe zones. However, and as indicated above, many evacuation roads cross private property, which could be a serious problem during an emergency. Furthermore, the safety zones are isolated meeting points without infrastructure and without links between them. Also, although the Communal Regulating Plan defines a tsunami risk zone as all areas located below 20 meters above sea level, the document does not establish standards for such zones; standards such as, permissible land use, land use restrictions, and land use intensity regulations should be clearly defined.

In regards to the social dimension, the planning documents include several polices related to the management of the territory at regional and local scales in the event of a disaster. For example, the Regional Emergency
Plan defines the Emergency Operations Committee (COE), which must be formed no more than 30 minutes after the disaster strikes. This committee encourages different modes of permanent communication between the ONEMI and several emergency organizations at national and regional levels. Nevertheless, it should be noted that Chile's highly centralized government, with high levels of administrative and institutional fragmentation, has hindered the successful planning and implementation of emergency and reconstruction efforts. Another difficulty in Chile is that local municipalities -legally autonomous public corporations with limited financial autonomy and no capacity to raise revenue internallystrongly depend on annual budget allocations at the national level; this in turn obstructs the development of strategic long-term projects (Herrmann, 2015).

\section{Conclusion}

In conclusion, the study of urban planning tools and the urban environment of Mehuín indicates that the most important dimension in building community resilience in the case of Mehuín, is the environmental dimension. Specifically, natural inundation buffers and natural resources for providing food, water, and fire after a disaster need to be urgently acknowledged, considered, and protected through statutory urban planning documents at regional and local scales. Considering that these documents currently focus on the physical dimension of resilience, more effort must be placed on recognizing the environmental dimension of resilience. Statutory planning tools set out regulations that are binding for all actors, and thereby ensure the compliance of norms by all involved parties, which often have conflicting interests. As indicated, statutory planning documents to define land use and risk zones only exist in Chile for urban areas within the urban boundary through the Communal Regulating Plan. However, for rural areas outside the urban areas statutory planning instruments for regulating land use are not available. This presents a great weakness for enhancing community resilience, since risk zones, no construction zones, buffers and land use in general need to be designated in a binding way to ensure the compliance of regulations by all actors. 
Addressing the challenge of resilience in planning clearly requires a transdisciplinary and integrative approach that differs from the current planning practices that mainly focus on physical systems. Further to this, the resilience thinking approach suggests that resilience is a process not an outcome: this might be the hardest issue to address in planning tools. Although this study shows that aspects of resilience are addressed in the planning of Mehuín, these are formulated to meet specific targets in a specific time frame and do not take into consideration the adaptive capacity of the town that is constantly evolving. Moreover, the current planning tools have not been able to anticipate coping with disasters. Rather the tools in place facilitate the reaction after a disaster, trying to rebuild what has been destroyed with the use of stronger regulations. Overall, there is no end to building community resilience: natural perturbations that might affect Mehuín can neither be one hundred percent predicted nor planned for. Hence, the resilience attributes found in this study are not decisive. The resilience thinking approach in a planning context, therefore, requires a more flexible framework of planning tools that can be adapted according to unexpected change. This should focus more on the process of building community resilience, than on the outcome of disaster.

With a 'resilience thinking' approach planners can consider the role of natural resources in facilitating community resilience in the event of a disaster. With this a plan can be generated that treats coastal territory as a dynamic system. Indeed, when planners discuss the emerging science of resilience and the concept of ecosystem services in adaptive urban planning and design, they should take into consideration the environmental, physical, and social dimensions of resilience. These dimensions must be integrated in planning to foster innovation that will improve adaptability in the face of change, disturbance, and uncertainty.

\section{Bibliographic References}

AHERN, J. From fail-safe to safe-to-fail: Sustainability and resilience in the new urban world. Landscape and Urban Planning, 2011, $\mathrm{N}^{\circ} 100$, p. 341-343.
ALISTE, E. \& PÉREZ, S. La reconstrucción del Gran Concepción: territorio y catástrofe como permanencia histórica. Revista de Geografía Norte Grande, 2013, No 54, p. 199-218.

ALLAN, P. \& BRYANT, M. Resilience as a framework for urbanism and recovery. Journal of Landscape Architecture, 2011, p. 34-45.

CASEN. Encuesta de Caracterización Socioeconómica Nacional. Santiago de Chile: Ministerio de Planificación (MIDEPLAN), 2009.

CASEN. Encuesta de Caracterización Socioeconómica Nacional. Santiago de Chile: Ministerio de Desarrollo Social, 2011.

CASEN. Encuesta de Caracterización Socioeconómica Nacional. Santiago de Chile: Ministerio de Desarrollo Social, 2013.

CHOU, J.S.; OU, Y.C.; CHENG, M.Y.; CHENG, M.Y. \& LEE, C.M. Emergency shelter capacity estimation by earthquake damage analysis. Natural Hazards, 2013, N 65, p. 2031-2061.

CORPORACIÓN NACIONAL FORESTAL (CONAF). Sistema de Información Territorial. Santiago de Chile: CONAF, 2006. Disponible en Internet: http://sit.conaf.cl/.

CUTTER, S.L.; BARNES, L.; BERRY, M.; BURTON, C.; EVANS, E.; TATE, E. \& WEBB, J. A place-based model for understanding community resilience to natural disasters. Global Environmental Change, 2008, № 18, p. 598-606.

CUTTER, S.L.; ASH, K.D. \& EMRICH, C.T. The geographies of community disaster resilience. Global Environmental Change, 2014, No 29, p. 65-77.

DAVOUDI, S.; SHAW, K.; HAIDER, L.J.; QUINLAN, A.E.; PETERSEN, G.; WILKINSON, C.; FUNFGELD, H.; MCEVOY, D. \& PORTER, L. Resilience: A Bridging Concept or a Dead End? "Reframing" Resilience: Challenges for Planning Theory and Practice Interacting Traps: Resilience Assessment of a Pasture Management System in Northern Afghanistan Urban Resilience: What Does it Mean 
in Planning Practice? Resilience as a Useful Concept for Climate Change Adaptation? The Politics of Resilience for Planning: A Cautionary Note. Planning Theory \& Practice, 2012, Vol. $13 ; \mathrm{N}^{\circ} 2$, p. 299-333.

FORBES, K. \& BROADHEAD, J. The role of coastal forests in the mitigation of tsunami impacts. Bangkok: Food and Agriculture Organization of the United Nations, 2007.

GOBIERNO DE CHILE. Ordenanza General de Urbanismo y Construcciones. Santiago de Chile, 2015.

GSAPP, LATIN LAB \& SANTIAGO RESEARCH CELL. Learning from 27F: A Comparative assessment of Urban Reconstruction Processes after the 2010 Earthquake in Chile. Santiago de Chile: GSAPP, LATIN LAB \& SANTIAGO RESEARCH CELL, 2015.

HERRMANN, G. Urban Planning and Tsunami Impact Mitigation in Chile after February 27, 2010. Natural Hazards, 2015, Vol. 79, $\mathrm{N}^{\circ} 3$, p. 1591-1620.

IDE CHILE. Infraestructura de Datos Geoespaciales. Santiago de Chile: Ministerio de Bienes Nacionales, 2014. Disponible en Internet: http://www.ide.cl/.

INSTITUTO NACIONAL DE ESTADÍSTICAS (INE). Censo de Población y Vivienda 2002. Santiago de Chile: INE, 2002.

INSTITUTO NACIONAL DE ESTADÍSTICAS (INE). Chile: Ciudades, Pueblos, Aldeas y Caseríos. Santiago de Chile: INE, 2005.

INGRAM, J.C. \& KHAZAI, B. Incorporating Ecology and Natural Resource Management into Coastal Disaster Risk Reduction. In: INGRAM, J.C.; DECLERCK, F. \& RIO, C.R.D. (editors). Integrating ecology and poverty reduction. New York: Springer, 2012, p. 369392.

INTERNATIONAL STRATEGY FOR DISASTER REDUCTION (ISDR). Hyogo Framework for Action 2005-2015: Building the Resilience of Nations and Communities to Disasters. Hyogo: ISDR, 2005.
LORITO, S.; ROMANO, F.; ATZORI, S.; TONG, X.; AVALLONE, A.; MCCLOSKEY, J.; COCCO, M.; BOSCHI, E. \& PIATANESI, A. Limited overlap between the seismic gap and coseismic slip of the great 2010 Chile earthquake. Nature Geoscience, 2011, January, p. 173-177.

MILLENIUM ECOSYSTEM ASSESSMENT. Ecosystems and Human Well-being: Synthesis. Washington, D.C.: Island Press, 2005.

MUNICIPALIDAD DE MARIQUINA. Memoria Explicativa. Plan Regulador Comunal de Mariquina. San José de la Mariquina: 2015 (Access in the Municipality).

NORRIS, F.; STEVENS, S.; PFEFFERBAUM, B.; WYCHE, K. \& PFEFFERBAUM, R. Community resilience as a metaphor, theory, set of capacities and strategy for disaster readiness. Community Psychology, 2008, N 41, p. 127 150.

OFICINA NACIONAL DE EMERGENCIA (ONEMI). Mehuín. Plan de Protección Civil ante Tsunami. Valdivia. 2013. Disponible en Internet: http://www.onemi.cl/wp-content/ uploads/2013/09/Mehuín.pdf

OFICINA NACIONAL DE EMERGENCIA (ONEMI). Plan Regional de Emergencia 2012. Valdivia. 2012.

QUINN, G.P. \& KEOUCH, M.J. Experimental design and data analysis for biologists. Cambridge: Cambridge University Press, 2002.

RENSCHLER, C.S.; FRAIZE, A.E.; ARENDT, L.A.; CIMELLARO, G.P.; REINHORN, A. \& BRUNEAU, M. A Framework for Defining and Measuring Resilience at the Community Scale: The PEOPLES Resilience Framework. New York, 2010.

ROCKEFELLER FOUNDATION. 100 Resilient Cities. In: The United States of America. New York: Rockefeller Foundation, 2015.

SILVERMAN, D. \& MARVASTI, A. Doing Qualitative Research; A Comprehensive Guide. New York: SAGE Publications Ltd, 2008. 
VALE, L.J. \& CAMPANELLA, T.J. The resilient city, how modern cities recover from disaster. New York: Oxford University Press, 2005.

VILLAGRA, P.; ROJAS, C.; OHNO, R.; XUE, M. \& GOMEZ, K. A GIS-base exploration of the relationships between open space systems and urban form for the adaptive capacity of cities after an earthquake: the cases of two Chilean cities. Applied Geography, 2014, N48, p. 64-78.
WALKER, B.; HOLLING, C.S.; CARPENTER, S.R. \& KINZIG, A. Resilience, adaptability and transformability in social-ecological systems. Ecology and Society, 2004, Vol. 9, $\mathrm{N}^{\circ} 2$, p. 5 .

WALKER, B. \& SALT, D. Resilience thinking: sustaining ecosystems and people in a changing world. Washington: Island Press, 2006. 